\title{
Infection: friend or foe to the development of asthma?
}

\author{
K-H. Carlsen*, P.J. Sterk ${ }^{\#}$
}

Of the most common diseases among humans, respiratory infections are important causes of disease and disability in high-income countries [1] and some of the most common causes of death in low-income countries, especially among children [2].

Since the late forties and the early fifties, severe bacterial infections have decreased in frequency and severity in industrialized countries. At the same time, allergy and asthma have increased, starting at the same time but especially from the late seventies and eighties. In Norway, an epidemiological study from 85 health districts showed a lifetime prevalence of asthma of $0.4 \%$ among schoolchildren [3], whereas in the mid-nineties it was 10-12\% [4]. In 1966-1971, the risk of acquiring asthma increased by $2.33 \%$ compared to 1946-1950 in 15 industrialized countries in Europe [5]. STRACHAN [6] formulated the hygiene hypothesis based upon the finding that children with siblings had fewer allergies than children without, and based this upon the finding that children with siblings had more respiratory infections early in life. Later findings, both epidemiological as well as basic scientific research [6], have supported this hypothesis. However, there are more complex relationships between infections and asthma (and allergy).

In this issue of European Respiratory Journal (ERJ), a new series of articles highlighting this topic from different points of view and based upon different types of scientific studies, starts with an article by vON Mutius [7], taking up the epidemiological part of this problem. vON Mutius [7] gives an impressive review of the existing epidemiological evidence.

Respiratory syncytial virus (RSV) is the most frequent cause of acute bronchiolitis and lower respiratory tract disease during infancy $[8,9]$. It is still not known why some infants acquire severe lower respiratory tract infection with symptoms of bronchial obstruction, while most young children only have symptoms of upper respiratory tract infection with RSV. It has been speculated that acute bronchiolitis is the cause of later obstructive airways disease during

\footnotetext{
*Voksentoppen National Centre of Asthma, Allergy and Chronic Lung Diseases in Children and Klosterstiftelsen, Research Institute of Paediatric Asthma, Respirology and Environment, Oslo, Norway. \# Dept of Pulmonology, Leiden University Medical Centre, Leiden, the Netherlands.

Correspondence: K-H. Carlsen, Voksentoppen National Centre of Asthma, Allergy and Chronic Lung Diseases in Children and Klosterstiftelsen, Research Institute of Paediatric Asthma, Respirology and Environment, Ullveien 14, N-0791 Oslo, Norway. Fax: 4722136505.
}

infancy, or that acute bronchiolitis occurs in infants with a pre-existing predisposition. It is accepted that certain pre-existing illnesses predispose to severe manifestations, such as congenital heart disease [10], immune deficiency [11] or prematurity [12]. Interestingly, a recent study reported that there was an association between the severity of RSV infection during infancy and the genetic locus of the IL8-251A allele, which tended to be associated with increased interleukin (IL)-8 production by lipopolysaccharide [13]. In order to respond with cytokine production, the response to RSV protein $\mathrm{F}$ in mice was dependent upon the presence of CD14 and Toll-like receptors type 4 [14]. Thus, there seems to be, at least in part, a genetic basis for the severity of acute bronchiolitis.

Acute bronchiolitis and RSV infections have been known for many years to be closely related to recurrent obstructive episodes after acute bronchiolitis [15-21]. The risk of recurrent obstructive episodes is most pronounced among hospitalized infants $[22,23]$, but it is also present in infants not admitted to hospital. BonT et al. [24] recently reported that RSV infections provoked increased IL-10 production, especially in children who later suffered from recurrent wheezing. However, it has been found that with increasing age, the impact of acute bronchiolitis upon recurrent obstructive episodes gradually diminishes [25, 26], although bronchial responsiveness may remain [27, 28]. A meta-analysis based upon follow-up studies taking up this problem was published, although strict inclusion criteria led to the inclusion of only six studies in the analysis [29].

Another aspect of disease occurring after acute RSV bronchiolitis has been highlighted by SIGURS et al. [30], who performed a carefully designed case-control follow-up study of patients admitted to hospital with RSV bronchiolitis compared to healthy children without allergic or obstructive airways disease. They followed the children until they were 3 [30] and 7 yrs of age [31]. At both 3 and 7 yrs of age they found acute bronchiolitis to be the most important factor predisposing for asthma, but they also found increased occurrence of allergic sensitization to both food and inhalant allergens [30, 31]. This latter finding has not been confirmed by many other studies. The features of recurrent obstructive episodes and asthma, as well as the possible effect of RSV infections upon allergic sensitization in infants and young children, will be addressed by WENNERGREN and KRISTJÁNSSON [32] in a comprehensive article in the present series.

It is a continuing debate what the mechanisms are 
underlying the relationship of acute RSV bronchiolitis with later occurring obstructive airways disease and the possible relationship with later allergic sensitization. Several study groups have performed experimental studies in mice and other animals to try to solve this problem. Some studies indicate that the timing of RSV infection, in relationship to possible allergen exposition, may determine whether the "patient" will react in a T-helper (Th)2-type way, with production of IL-4 and IL-5, or in a Th1-type way, with predominant interferon- $\gamma$ production [33]. During those circumstances and in these animal models, treatment with antibodies to IL-5 inhibits airway inflammation and hyperresponsiveness [32]. However, it is as yet unknown whether this can also be supported in humans. Other groups have focused on the role of RSV lower respiratory tract infection in potentiating neurogenic-mediated inflammation with increased microvascular permeability caused by stimulation of sensory nerves during RSV infection, and an upregulation of the high affinity receptor for substance $\mathrm{P}$ [34]. The animal experiments may provide important information about the mechanisms involved in human children with RSV infection. This is highlighted in a very interesting article in the present series by SCHWARzE and GelFand [35].

Do infections represent a friend or foe in the development of asthma and allergy in the young child? During recent years, important immunolgical knowledge on the development of allergy has been acquired. Holt and coworkers [36, 37] have focused upon the development of the immune system in the very young and the maturing child, from a Th2-dominating immune system at birth to increasing Th1 function through stimulation by infectious agents. RENZ and HERZ [38], in their excellent review in the present series, provide insight into both immunological mechanisms and the recent developments in the research within this particular field, thus making it easier for the reader to understand.

Another aspect of the relationship of respiratory virus infections with obstructive airways disease is the role of respiratory virus infections, and especially rhinovirus infections, in causing acute exacerbations of asthma. This was described many years ago $[39,40]$ and found to be the most important cause of acute asthma in children [41-43]. It is of particular interest that the intracellular adhesion molecule- 1 has been found to be the major human receptor for rhinovirus [44].

Reports in recent years have focused on the relationship of persisting intracellular pathogens with obstructive airways disease. Chlamydia may play a role in the initiation of obstructive airways disease and asthma [45-47], as well as in the aggravation and exacerbation of asthma and obstructive airways disease [48-51]. vON HERTZEN [52] highlights both epidemiological, clinical and experimental data in an impressive review of the role of Chlamydia in relation to this topic [52].

Accordingly, viral and bacterial infections have important implications for asthma and other forms of obstructive airways disease, as well as for the development of allergy. The present series of articles starting in this issue of $E R J$ will highlight recent scientific development within this area.

In the present series, the authors have been asked to evaluate the evidence of the various studies included in their review articles. This is, of course, much more difficult to perform in epidemiological follow-up studies and experimental studies than in therapeutic trials, but it is felt to be important that the experts in the field should also assess the evidence in relation to the different hypotheses in this very complicated and intriguing field. It is hoped that this will be useful to the reader and possibly provide input for later reviews that take into account the evidence in topics other than therapeutic research.

\section{References}

1. Chanock RM, Parrot RH. Acute respiratory disease in infancy and childhood. Present understanding and prospects for prevention. Pediatrics 1965; 36: 21-39.

2. Denny FW, Loda FA. Acute respiratory infections are the leading cause of death in children in developing countries. Am J Trop Med Hyg 1986; 35: 1-2.

3. Claussen O. Asthma prevalence among school children in Norway. Nord Med 1948; 37: 525.

4. Nja F, Roksund OD, Svidal B, Nystad W, Carlsen KH. Asthma and allergy among schoolchildren in a mountainous, dry, non-polluted area in Norway. Pediatr Allergy Immunol 2000; 11: 40-48.

5. Sunyer J, Anto JM, Tobias A, Burney P. Generational increase of self-reported first attack of asthma in fifteen industrialized countries. European Community Respiratory Health Study (ECRHS). Eur Respir $J$ 1999; 14: 885-891.

6. Strachan DP. Family size, infection and atopy: the first decade of the "hygiene hypothesis". Thorax 2000; 55: Suppl. 1, S2-S10.

7. von Mutius E. Infection: friend or foe in the development of atopy and asthma? The epidemiological evidence. Eur Respir J 2001; 18: 872-881.

8. Sims DG. Acute bronchiolitis in infancy. Nurs Times 1979; 75: 1842-1844.

9. Carlsen KH, Ørstavik I, Halvorsen K. Respiratory syncytial viral infections in Oslo 1972-1978. II. Clinical and laboratory studies. Acta Paediatr Scand 1980; 69: 723-729.

10. MacDonald NE, Hall CB, Suffin SC, Alexson C, Harris PJ, Manning JA. Respiratory syncytial viral infection in infants with congenital heart disease. $N$ Engl J Med 1982; 307: 397-400.

11. Hall CB, Powell KR, MacDonald NE, et al. Respiratory syncytial virus infections in children with compromised immune function. N Engl J Med 1986; 315: 77-81.

12. Stevens TP, Sinkin RA, Hall CB, Maniscalco WM, McConnochie KM. Respiratory syncytial virus and premature infants born at 32 weeks' gestation or earlier: hospitalization and economic implications of prophylaxis. Arch Pediatr Adolesc Med 2000; 154: 5561.

13. Hull J, Thomson A, Kwiatkowski D. Association of respiratory syncytial virus bronchiolitis with the interleukin 8 gene region in UK families. Thorax 2000; 55: 1023-1027.

14. Kurt-Jones EA, Popova L, Kwinn L, et al. Pattern 
recognition receptors TLR4 and CD414 mediate response to respiratory syncytial virus. Nature Immunol 2001; 1: 398-401.

15. Wittig HJ, Cranford NJ, Glaser J. The relationship between bronchiolitis and allergic asthma. J Allergy 1959; 30: 19-23.

16. Zweiman B, Schoenwetter WF, Hildreth EA. The relationship between bronchiolitis and allergic asthma. A prospective study with allergy evaluation. $J$ Allergy 1966; 37: 48-53.

17. Hyde JS, Saed AM. Acute bronchiolitis and the asthmatic child. J Asthma Res 1966; 4: 137-154.

18. Zweiman B, Schoenwetter WF, Pappano JE, Tempest B, Hildreth EA. Patterns of allergic respiratory disease in children with a past history of bronchiolitis. J Allergy Clin Immunol 1971; 48: 283-289.

19. Rooney JC, Williams HE. The relationship between proved viral bronchiolitis and subsequent wheezing. J Pediatr 1971; 79: 744-747.

20. Mok JYQ, Simpson H. Outcome for acute bronchitis, bronchiolitis and pneumonia in infancy. Arch Dis Child 1984; 59: 306-309.

21. Carlsen KH, Larsen S, Ørstavik I. Acute bronchiolitis in infancy. The relationship to later obstructive airways disease and characterization of infants at risk. Eur J Respir Dis 1987; 70: 86-92.

22. Wennergren $\mathrm{G}$, Hansson $\mathrm{S}$, Engstrom $\mathrm{I}$, et al. Characteristics and prognosis of hospital-treated obstructive bronchitis in children aged less than two years. Acta Paediatr 1992; 81: 40-45.

23. Kuikka L, Reijonen T, Remes K, Korppi M. Bronchial asthma after early childhood wheezing: a follow-up until 4.5-6 years of age. Acta Paediatr 1994; 83: 744-748.

24. Bont L, Heijnen CJ, Kavelaars A, et al. Monocyte IL-10 production during respiratory syncytial virus bronchiolitis is associated with recurrent wheezing in a one-year follow-up study. Am J Respir Crit Care Med 2000; 161: 1518-1523.

25. Stein RT, Sherrill D, Morgan WJ, et al. Respiratory syncytial virus in early life and risk of wheeze and allergy by age 13 years. Lancet 1999; 354: 541-545.

26. McConnochie KM, Roughmann KJ. Wheezing at 8 and 13 years: changing importance of bronchiolitis and passive smoking. Pediatr Pulmonol 1989; 6: 138146.

27. Korppi M, Kuikka L, Reijonen T, et al. Bronchial asthma and hyperreactivity after early childhood bronchiolitis or pneumonia. An 8-year follow-up study. Arch Pediatr Adolesc Med 1994; 148: 10791084 .

28. Wennergren G, Amark M, Amark K, Oskarsdottir S, Sten $\mathrm{G}$, Redfors S. Wheezing bronchitis reinvestigated at the age of 10 years. Acta Paediatr 1997; 86: 351355.

29. Kneyber MCJ, Steyerberg EW, de Groot R, Moll HA. Long-term effects of respiratory syncytial virus (RSV) bronchiolitis in infants and young children: a quantitative review. Acta Paediatr 2000; 89: 654-660.

30. Sigurs N, Bjarnason R, Sigurbergsson F, Kjellman B, Björkstén B. Asthma and immunoglobulin E antibodies after respiratory syncytial virus bronchiolitis: a prospective cohort study with matched controls. Pediatrics 1995; 95: 500-505.

31. Sigurs N, Bjarnason R, Sigurbergsson F, Kjellman B. Respiratory syncytial virus bronchiolitis in infancy is an important risk factor for asthma and allergy at age 7. Am J Respir Crit Care Med 2000; 161: 1501-1507.

32. Wennergren G, Kristjánsson S. Relationship between respiratory syncytial virus bronchiolitis and future obstructive airway diseases. Eur Respir J 2001 (in press).

33. Schwarze J, Cieslewicz G, Hamelmann E, et al. IL-5 and eosinophils are essential for the development of airway hyperresponsiveness following acute respiratory syncytial virus infection. J Immunol 1999; 162: 2997-3004.

34. Piedimonte G, King KA, Holmgren NL, Bertrand PJ, Rodriguez MM, Hirsch RL. A humanized monoclonal antibody against respiratory syncytial virus (palivizumab) inhibits RSV-induced neurogenicmediated inflammation in rat airways. Pediatr Res 2000; 47: 351-356.

35. Schwarze J, Gelfand EW. Respiratory viral infections as promoters of allergic sensitization and asthma development: lessons from animal models. Eur Respir $J 2001$ (in press).

36. Holt PG. Environmental factors and primary T-cell sensitisation to inhalant allergens in infancy: reappraisal of the role of infections and air pollution. Pediatr Allergy Immunol 1995; 6: 1-10.

37. Holt PG, Yabuhara A, Prescott S, et al. Allergen recognition in the origin of asthma. Ciba Found Symp 1997; 206: 35-49.

38. Renz H, Herz U. The bidirectional capacity of bacterial antigens to modulate allergy and asthma. Eur Respir $J 2001$ (in press).

39. Minor TE, Dick EC, DeMeo AN, Ouellette JJ, Cohen M, Reed CE. Viruses as precipitants of asthmatic attacks in children. JAMA 1974; 227: 292-298.

40. McIntosh K. Bronchiolitis and asthma: possible common pathogenetic pathways. J Allergy Clin Immunol 1976; 57: 595-604.

41. Carlsen KH, Ørstavik I, Leegaard J, Høeg H. Respiratory virus infections and aeroallergens in acute bronchial asthma. Arch Dis Child 1984; 59: 310-315.

42. Johnston SL, Pattemore PK, Sanderson G, et al. Community study of viral infections in exacerbations of asthma in 9-11 year old children. BMJ 1995; 310: 1225-1229.

43. Cheung D, Dick EC, Timmers MC, de Klerk EP, Spaan WJ, Sterk PJ. Rhinovirus inhalation causes long-lasting excessive airway narrowing in response to methacholine in asthmatic subjects in vivo. Am J Respir Crit Care Med 1995; 152: 1490-1496.

44. Greve JM, Davis G, Meyer AM, et al. The major human rhinovirus receptor is ICAM-1. Cell 1989; 56 : 839-847.

45. Emre U, Roblin PM, Gelling M, et al. The association of Chlamydia pneumoniae infection and reactive airway disease in children. Arch Pediatr Adolesc Med 1994; 148: 727-732.

46. Hahn DL, McDonald R. Can acute Chlamydia pneumoniae respiratory tract infection initiate chronic asthma? Ann Allergy Asthma Immunol 1998; 81: 339344.

47. Von Hertzen L, Toyryla M, Gimishanov A, et al. Asthma, atopy and Chlamydia pneumoniae antibodies in adults. Clin Exp Allergy 1999; 29: 522-528.

48. Allegra L, Blasi F, Centanni S, et al. Acute exacerbations of asthma in adults: role of Chlamydia pneumoniae infection. Eur Respir J 1994; 7: 2165-2168.

49. Black PN, Scicchitano R, Jenkins CR, et al. Serological 
evidence of infection with Chlamydia pneumoniae is related to the severity of asthma. Eur Respir J 2000; 15: 254-259.

50. Martin RJ, Kraft M, Chu HW, Berns EA, Cassell GH. A link between chronic asthma and chronic infection. J Allergy Clin Immunol 2001; 107: 595-601.

51. ten Brinke A, van Dissel JT, Sterk PJ, Zwinderman
AH, Rabe KF, Bel EH. Persistent airflow limitation in adult-onset nonatopic asthma is associated with serologic evidence of Chlamydia pneumoniae infection. J Allergy Clin Immunol 2001; 107: 449-454.

52. von Hertzen LC. Role of persistent infection in the control and severity of asthma: focus on Chlamydia pneumoniae. Eur Respir J 2001 (in press). 